\begin{abstract}
Iranica
Abstracta Iranica Revue bibliographique pour le domaine irano-aryen

Volume 32-33 | 2013

Comptes rendus des publications de 2009-2010
\end{abstract}

\title{
Kristin Kleber. dātu ša šarri: Gesetzgebung in Babylonien unter den Achämeniden
}

\section{Astrid Nunn}

\section{(2) OpenEdition}

1 Journals

Édition électronique

URL : http://journals.openedition.org/abstractairanica/40347

DOI : 10.4000/abstractairanica.40347

ISSN : 1961-960X

Éditeur :

CNRS (UMR 7528 Mondes iraniens et indiens), Éditions de l'IFRI

\section{Édition imprimée}

Date de publication : 1 décembre 2013

ISSN : 0240-8910

\section{Référence électronique}

Astrid Nunn, « Kristin Kleber. dātu ša šarri: Gesetzgebung in Babylonien unter den Achämeniden », Abstracta Iranica [En ligne], Volume 32-33 | 2013, document 88, mis en ligne le 01 juillet 2016, consulté le 26 septembre 2020. URL : http://journals.openedition.org/abstractairanica/40347 ; DOI : https:// doi.org/10.4000/abstractairanica.40347

Ce document a été généré automatiquement le 26 septembre 2020.

Tous droits réservés 


\title{
Kristin Kleber. dātu ša šarri: Gesetzgebung in Babylonien unter den Achämeniden
}

\author{
Astrid Nunn
}

\section{RÉFÉRENCE}

Kristin Kleber. « dātu ša šarri: Gesetzgebung in Babylonien unter den Achämeniden ». ZAR (Zeitschrift für Altorientalische und Biblische Rechtsgeschichte) 16, 2010, p. 49-75.

1 L'Empire achéménide, comme avant lui, les empires assyrien et néo-babylonien, rassemblait de nombreuses entités ethniques à traditions légales différentes. L'A. s'interroge sur l'adaptation du droit babylonien. Pour ce, l'A. analyse les 12 textes accadiens de Babylonie où apparait le mot perse «dātu» qui signifie «droit, loi, décret ». En résumé, les dātu possédaient un caractère normatif, étaient écrits et réglaient aussi bien les tarifs que les peines. Qu'il s'agisse de droit ou d'une loi est une question de définition.

\section{AUTEURS}

\section{ASTRID NUNN}

Université de Munich 